\title{
THE STRUGGLE OF VICTORIAN WOM EN IN NOVEL "LITTLE WOMEN" BY LOUISA MAY ALCOTT
}

\author{
Cinda Amilia Rahman \\ English Literature Department, Faculty of Culture Science, Muhammadiyah \\ University of Gorontalo \\ hijrahparis@gmail.com
}

\begin{abstract}
This research discuses Louisa May Alcott's novel, "Little Women". It is a story about four sisters and mother in the March Family. The novel, which has a background in the Victorian Era, addresses many issues about women. The description of women at that time, positions in the Family, Education and Public work environment. Therefore this study aims to determine aspects of the struggle of women in Victorian era in terms of family, education, and Public work environment using a gynocriticism approach. The data used documentation data where data comes from novels and other supporting sources. The results of this study researchers found that there were aspects of women's struggle at that time in the novel "Little Women" in Family, Education and Public work environment. In addition, researcher found a relation between the life story of author Louisa May Alcott and the "Little Women" novel that has been presented in some data.
\end{abstract}

Keywords: Victorian Era, Gynocriticism, Louisa May Alcott, Little Women.

\section{INTRODUCTION}

The Victorian era is often regarded as a high point in English literature and it is the literature that coincides in extent with the reign of Queen Victoria, and covers the whole of the nineteenth century. It forms a link and between the writing of the romantic period and the very different modern literature in the 20th century. It reflects the intellectual patterns of the Victorian age, dealing with the status question through on the examinations of society, the law, industrialism and historical ideals (Fletcher, 2002).

In this era, literature was still developing from the era to the previous era Romanticism. The Era of Romanticism is a period of compilation of many literary works related by the French Revolution which had a lot about freedom, Contact, and brotherhood. The third ideal leads to that commitment basically humans are all good, but the social institutions around those who make a bad contribution to their natural good. The natural goodness of humans can be obtained by freeing them from approving-socializing their degrees through brotherhood. This made the French Revolution a starting point the development of the flow of growth and 
the planning of objectives that existed in Europe at that time and make this ideal classic explicit and encouraging Romantic Movement in England. Romantic movements in the United Kingdom more spawned literary works in the form of poetry.

Unlike the era of Romanticism, the Victorian era became a transition period much of the contradiction between religious feeling and scientific side. The Victorian Era is the era that coincides with the reign of Queen Victoria in 1837. It is characterized by many changes that make the reign of Victoria the most progressive in English history (Fletcher, 2002).

The Victorian era was a transitional period and an important one of English literature. It dealt with the contemporary issues and problems of the day including social economic, religious and intellectual subjects, troubles surrounding the industrial revolution, in addition to that, changes in the role of women who were not expected to have interest in literature or any other field, who had limited status in Victorian society (Fatima, 2012).

In society, women faced many difficulties because of the vision of the ideal women. During the era, women did not have rights, abused and oppressed as a result of policy in which discriminatory laws were existed. Women could not become property owners could not hold professional jobs apart from teachers or a domestic servant, factory workers or agricultural labors (Mitchell, 2009). Society did not consider that women needed formal education. As a result, it was rare to find women in skilled jobs that required higher or intermediate education. Women then were generally expected to be housekeepers or housewives.

Little Women was first published on 30 september 1868, three years after the end of the American Civil War. The setting of time of the novel takes the period in the recent nineteenth century life in America it is the difficult time for women to express themselves in public (Ratnaningrum, 2009). The situation that influenced Louisa May Alcott to write a story about the struggle of the four sisters with their mother without their father. The four March Sisters have different characters. Meg, the oldest, she is beautiful and has a dream to become a queen who wears a beautiful dress. Jo, the second, she is tomboyish and temperament.

\section{British, Jurnal Bahasa dan Sastra Inggris}


Beth, the third, she is shy and has a talent to play piano. Amy, the youngest, likes drawing and immature. The conflicts in this novel begin when Mr. March had to go away as the minister of religion with the army in the American Civil War. The situation makes girls of March work in order to get money and have to survive to stay alive.

The story of Little Women has a lot of similar from the original story of the author, Louisa May Alcott. Louisa May Alcott is the second of four children. Her first sister named Anna Bronson Alcott, this character in Little Women inspired her made character as Meg. The second-youngest March sister is based on Alcott's sister by the same name, Elizabeth Sewall Alcott, The youngest March sister is based on the youngest Alcott sister Abigail May Alcott. And Jo's character is a representation of Louisa May Alcott's own character (Bailey, 2010).

\section{RESEARCH METHOD}

This research use descriptive qualitative method. It was a research design part of qualitative method that allows the researcher to describe a phenomenon by presenting the facts in rich detail without attempting to interpret them. Moleong (2007:6) says: Qualitative research is research that aims to understand the phenomenon of what is experienced by the subject of the study such behavior, perception, motivation, action, and so on, in a holistic manner and by way of description in the form of words and language, in a specific context that is natural and with utilizing a variety of natural method. It means that the qualitative research focused on the understanding in the concept of the research and human experience.

In this case the researcher analyze how is the Struggle of Victorian Women in the novel Little Women by Louisa May Alcott. The researcher applied gyno criticism approach.

\section{RESEARCH FINDING AND DISCUSSION}

This part is present research finding and discussion. In this part the researcher presents the answer of problem statements. 


\section{Findings}

There are many thought that women are dominated by men in family and society and treated as the 'second' society because women are weak and powerless. Women are supposed to be good mothers and women are only to speak when they are spoken to. In the Victorian era, women must go through social classes so that they can determine the level of well-being for women themselves (Mitchell, 2009). For this reason, women must fight against various treatments that must be done, discriminate and change the stereotypes in the society. The struggle of women in this case was published in the novel Little Women by Louisa May Alcott who had to fight for life with their own support without men struggling through obtaining Feminism and Biographical approach. Therefore, some of the data below presents aspects 'of Family, Education and Public Works Environment.

\section{a. Family aspects}

In the novel Little Women Louisa May Alcott emphasized on the family aspect because in this aspect the novel depicts the struggles of four March Sisters and a mother facing the harshness of life in Victorian times because their father was in the Civil War. Their father, Mr. March, is away from home in Washington, where the war is, and Mrs. March cares the four daughters with their companion, Hannah. One day, a letter comes to the March informed that Mr. March is seriously ill and asked Mrs. March to come. Here, to help Mrs. March finance the trip, Jo, make a big sacrifice to cut her only beauty, her hair, and sells it and many other struggle that shows family aspect in this novel. Family aspects are illustrated in the novel little women as follows.

Data 01

"Mother didn't say anything about our money, and she won't wish us to give up everything. Let's each buy what we want, and have a little fun. I'm sure we work hard enough to earn it," cried Jo, examining the heels of her shoes in a gentlemanly manner." (page 6)

The data above tells us that in March the Sisters who were at home with the Christmas situation were no father beside them. Their father was in the Civil War to devote herself just like another man at that time. The women were at home. At 
that time, their mother Marmee was working outside to support their family without Father. March sisters and Marmee live with a servant who is very loyal to accompany them namely Hannah, an old woman. At that time, they were receiving a Christmas present and each of them was gifting what items they would buy for the Christmas gift. On the other hand, they also want to buy Marmee a Christmas present, but the money they have will not be enough if they have to buy Marmee a present. That's where Jo said "Mother doesn't say anything about our money, and she won't expect us to give up everything ...". Marmee also didn't expect anything and then continued with "Let's each buy what we want, and have a little fun. I'm sure we work hard enough to get it". This shows March Sisters work hard to get money to support their families.

Women in Victorian Era were indeed made as "the angle of the house" but the struggles carried out by March Sisters who worked to earn money to support their families were the choice that shows us that of women's independence and women's movements at that time already existed. According to Grylls (1949) Single women are indeed difficult to survive in this era, they are only expected to be human beings who will serve their husbands later but most of them also continue to work to earn money.

Based on book Louisa May Alcott her life, letters, and Journals (1898) by Ednah D.Cheney who wrote about the biography of Louisa May Alcott stated that Louisa was a daughter who was very hardworking to get money for her family. As a second child, she is a child with a leadership spirit among other children. In the struggle in the Victorian era she was also a feminist who fought for women's rights at the time.

Data 02

"We shouldn't enjoy ourselves half so much as we do now. But it does seem so nice to have little suppers and bouquets, and go to parties, and drive home, and read and rest, and not work. It's like other people, you know, and I always envy girls who do such things, I'm so fond of luxury," said Meg, trying to decide which of two shabby gowns was the least shabby." (page 53)

The Christmas atmosphere is still felt even though a week has passed. Christmas without father, only Marmee and March Sisters. The March Sisters are 
indeed children who patiently accept the situation because they are cared for by a very wise mother. They are implanted in many family values which are packaged in the tenderness of a mother. So it wasn't surprising at that time, those who were lazing to get up from holidays were encouraged by their sister Meg. Meg indeed transformed into a very mature sister and so loved her sisters. Although she is an obsessed character to be a rich woman who only needs to sit back at home and does not need to work and have a variety of beautiful dresses.

According to Farber (in Gunindi, 2011) family struggles, especially in the Victorian Era, are something that binds something to others, so that this can make them one. Something that supports one another. Also do not forget that it can affect the values of culture and society. Women who were living under pressure, who had to fight against the rigors of life in discrimination were reflected in this novel. However, in the biography of Louisa May Alcott in Louisa May Alcott's book Her Life, Letters and Journals (1898) were not found that Anna Bronson Alcott who in the novel representative by Meg behaved like that.

\section{b. Education aspects}

March Family's life struggle is not easy, this is included in the education aspect. Meg decides to work, Jo decides to work and helps Aunt March, Beth studies at Home, while Amy goes to school. Education reflected in the Little Women novel shows that at that time in the Victorian era there were two types of education, namely Informal Education and Formal Education. The struggle in Education aspects that happened in March Family shows in the data below.

Data 03

"for you don't have to go to school with impertinent girls, who plague you if you don't know your lessons, and laugh at your dresses, and label your father if he isn't rich, and insult you when your nose isn't nice." (page 7)

The data above shows Amy's struggle that is often ostracized at school. She often receives unfair treatment at school. As a child born to a poor family, she often gets ridicule from her friends. At that time, March sisters were sitting and telling stories about each other's complaints and thought that their struggle was more than others, until Amy issued a statement like the data above. Life in the

\section{British, Jurnal Bahasa dan Sastra Inggris}


Victorian era, which is all seen from the point of view of social class and discriminated based on wealth, is seen based on what clothes you are using, whose children, and how family conditions are not easy.

Amy is the only family member to sit in a formal school. In Victorian times education was divided into two formal education and informal education. According to Demir (2015) Formal education is education carried out by middle class children while informal education is taught at home. Amy encountered many difficulties in aspects of her education, especially at school, because she came from a social class that was different from her friends. Sister Louisa May Alcott, named Abby May Alcott, who is a representation of Amy, also received formal education. She was very good at painting like Amy. In his work Louisa May Alcott indeed connects many aspects of her life in the novel.

Data 04

"She loved music so dearly, tried so hard to learn, and practiced away so patiently at the jingling old instrument, that it did seem as if someone (not to hint Aunt March) ought to help her. Nobody did, however, and nobody saw Beth wipe the tears off the yellow keys, that wouldn't keep in tune, when she was all alone. She sang like a little lark about her work, never was too tired for Marmee and the girls, and day after day said hopefully to herself,' I know I'll get my music some time, if I'm good." (page 61)

The characteristics of March sisters are different, but even though their characters are different they have their own expertise. One of them was Beth who was very good at playing the piano. In the aspect of education, she is not schooled in a formal school. Beth is too shy to go to school. Her parents tried to send him to school, but she became so tormented that they decided to leave it as she pleased. So Beth learned at home, with their father gone, and their mother was called to donate their labor and expertise to the Soldiers' Aid Society, Beth continued to study on her own as well as possible.

Although Beth rarely complains she really wants to go to formal school. However, in the Victorian era it was natural for a woman to rely on her musical ability at home and learn various kinds of expertise at home. According to Demir (2015) Victorian ideology at that time, required women to have the ability in the world of art, music and language to become an angle of the house. In the life of 
Louisa May Alcott, Elizabeth her sister also has the same expertise that is having the ability to play music.

\section{c. Public Work Environment aspects}

The absence of their father because of the war gives bad impacts to the March family especially in financial. The situation makes the children work in order to get the money to help finance life. Meg works as a governess in a rich family, Jo as a companion in Aunt March, an old widow. Mrs. March is a very kind mother. She always cares her daughters with love, motivates them in every situation and teaches them to help the poor. The March sisters build a good relationship with their rich next-door neighbor, Mr. Lawrence, and his grandson, Laurie. The Lawrence always helps The March in facing their life without father especially in financial. Public environment aspect that happened in March family shows in the data below.

Data 05

"How would you like to be shut up for hours with a nervous, fussy old lady, who keeps you trotting, is never satisfied, and worries you till you you're ready to fly out the window or cry?" (page 6)

March sisters struggle to get money to support their families. There are so many obstacles that they go through in the work environment. The above data shows Jo's sentence that she complained about Bibi March which was very annoying. She would not be happy working there, but there was one source of happiness that made her feel at home, namely a large library owned by Bibi March at his home. If Bibi March falls asleep, then Jo will go to the library. In Victorian times it was not surprising that women's work did indeed become domestic servants. As for Louisa May Alcott, her work on her aunt is the same as that described in the Little Women novel.

Data 06

"It's naughty to fret, but I do think washing dishes and keeping things tidy is the worst work in the world. It makes me cross, and my hands get so stiff, I can't practice well at all." And Beth looked at her rough hands with a sigh that any one could hear that time." (page 7)

The data above shows Beth's complaint saying that she is also struggling against this life. Not only Meg struggled in her work environment, Jo struggled British, Jurnal Bahasa dan Sastra Inggris 
against her frustration with aunty March but he persisted for the sake of money, and Amy often complained that she was always ridiculed at school. But Beth also said that taking care of the house was not easy. From data 01 to data 02 it is similar to Brozak (2010) women in that era were servants to play jobs because the middle class would work on the upper class and for women that stayed at home they worked to prepare themselves become housewife and the man as the breadwinner.

\section{CONCLUSION AND SUGGESTION}

In this section the researcher gives conclusion that in analyzing the novel by Louisa May Alcott, the researcher found various values of struggle in her novel. Such as struggles in aspects of family, education, and public work environment. March family struggle is not easy to live everyday life. They have to live without their father and even have to work to add their income. Their togetherness and responsibility to each other teach us that family makes you strong. In addition, the researcher found similarity of this novel with Louisa's life.

\section{REFERENCES}

Bailey, W, Susan. 2010. Comparing the March sisters with their real life counterparts. (https://louisamayalcottismypassion.com/2010/11/11/compar ng-the-march-sisters-with-their-real-life-counterparts/.Accessed on May 4, 2018, 3.14 PM)

Cheney,D.Ednah.1898.Louisa May Alcott : Her life, letters, and Journals. Boston: Little Brown Company

Fatima, Merizig. 2012. The Status of Women in the Nineteenth Century Victorian England. Kasdi Merbah Ouargala University.

Fletcher, R, H. 2002 History of English Literature. (http://elibrary.bsu.az/books_400/N_22.pdf. Accessed on May 4, 2018, $2.45 \mathrm{PM})$.

Grylls, R. Glynn.1949. "Emancipation of Women." Ideas and Beliefs of the Victorians. London: Sylvan

Moleong, Lexy J.2007.Metode Penelitian Kualitatif. Bandung: Remaja Rosdakarya.

Mitchell, S. 2009.Daily life of Victorian England.Second Edition. Great Britain. 